\title{
UVODNIK
}

\section{PO DESETIH LETIH V ZAVEZNIŠTVU}

Ko smo v začetku leta napovedali, da bomo tretjo številko Sodobnih vojaških izzivov namenili desetletnici Republike Slovenije v Natu, nismo pričakovali tako dobrega odziva. Prejeli smo članke avtorjev, ki zelo dobro poznajo zgodovino slovenskih prizadevanj za pridružitev zavezništvu, hkrati pa jih je večina pri tem tudi osebno sodelovala. Ker so še vedno prisotni in aktivni na svojem profesionalnem področju, ima njihov pogled v pretekle dogodke posebno osebno noto, pogled v prihodnost pa je obogaten s teoretično in izkustveno noto.

Žal vseh člankov, ki smo jih dobili, ne moremo objaviti. Ključno vodilo pri izboru je bila osredotočenost na obrambno-vojaške vsebine, saj smo želeli pozornost nameniti predvsem vsebinam, ki jim je naša publikacija namenjena in so opredeljene v njenih aktih kot temeljno poslanstvo.

Leta 2009, ko smo s posebno tematsko številko zaznamovali peto obletnico članstva v zavezništvu in šestdesetletnico njegovega delovanja, so bile objavljene teme zelo zanimive državam v regiji Jugovzhodne Evrope, ki so stopale po poti, ki smo jo v Sloveniji že prehodili. Tako računamo, da bo tokratna številka zanimiva ljubiteljem obrambno-vojaških vsebin, mlajšim generacijam in vsem tistim, ki bodo morda še stopili na pot približevanja zavezništvu oziroma vstopanja vanj. Kako uspešni smo bili, lahko ugotovite v nadaljevanju.

Članek z naslovom Nato po letu 2014 - Nazaj h koreninam ali naprej v prihodnost? avtorjev Uroša Lampreta in Staše Novak predstavlja zavezništvo danes, aktualne varnostne trende, ki se pojavljajo v svetu, in odzive nanje. Pravita, da nazaj $\mathrm{h}$ koreninam ali naprej $\mathrm{v}$ prihodnost ne pomeni dveh različnih smeri, ampak povsem nekaj drugega. 
Milan Jazbec $v$ teoretičnem in praktičnem smislu ponudi pregled nad slovenskimi izkušnjami v času, ki je osrednja tema te številke. Uporablja termin učenje iz izkušenj in naslov njegovega članka Slovenija in Nato - dolga in vijugasta pot ni zgolj simboličen.

Pregled delovanja Slovenske vojske in njenih izkušenj iz zavezništva je pripravil Andrej Osterman. V članku z naslovom Republika Slovenija v Natu - Slovenska vojska deset let pozneje je predstavil ključne spremembe in napredek slovenskih oboroženih sil.

Obveščevalno-varnostnemu področju sta se posvetila Damir Črnčec in Janez Urbanc, ki v članku z naslovom Racionalizacija obveščevalno-varnostnih struktur v Natu in Evropski uniji podrobno pojasnita spremembe v organiziranosti in delovanju obveščevalno-varnostne skupnosti v mednarodnem okolju ter slovensko vlogo $\mathrm{v}$ njej.

Aljoša Selan je z naslovom Prispevek Slovenije $k$ programu za reintegracijo in spravo v Afganistanu - pogled svetovalca za analize politik pripravil predstavitev aktivnosti v tej državi po postopnem umiku zavezniških sil, da bi se njeni prebivalci kar najbolje pripravili na samostojen in kakovosten vsakdanjik.

Normativna vloga zavezništva pri nekonvencionalnih varnostnih grožnjah kibernetična obramba držav članic je naslov članka Adriane Dvoršak. Odpira aktualno problematiko, ki se spreminja tako zelo hitro, da se varnostne strukture že danes zavedajo svoje morebitne ogroženosti. Za učinkovito zaščito bo treba še veliko storiti.

Vsem avtorjem se zahvaljujemo za opravljeno delo in trud, še posebno, da so bili pripravljeni z nami deliti svoje znanje, izkušnje in poglede.

K pisanju vabimo vse tiste, ki morda trenutno samo razmišljate o tem, da bi kaj pripravili, pa se še niste čisto odločili.

Srečno. 